\title{
Upaya Peningkatan Penjualan Produk Batu Bata di Desa Kuto Sari Kecamatan Belitang III Kabupaten Ogan Komering Ulu Timur
}

\author{
Helisia \\ Management Departement, STIE Trisna Negara, Sumatera Selatan \\ e-mail: helisia.TN@gmail.com
}

\begin{abstract}
Efforts to increase sales is a way that can be done to increase production which will be accompanied by increased revenue, increased profits or profits. There are many ways you can do to increase sales including disseminating information through promotions, price discounts, improving product quality, collaborating with other parties. Kutosari Village is one of the villages in the East OKU Regency, Belitang III District. One of the residents' livelihoods is as a brick maker. In addition to raw materials that are easily obtained, brick making has become the expertise of most residents, because the production of these bricks has been carried out for generations. So far, the marketing of bricks in the village of Kuto Sari is done by sellers who only place their products in front of their homes, waiting for consumers to come to the brick production site themselves. Therefore, the marketing of bricks must be increased in a more vigorous way through promotion through social media, online, coming to building shops to collaborate and many other things in order to increase sales of brick products to be achieved in the village of Kuto Sari.
\end{abstract}

Keywords: increased combination, bricks

\begin{abstract}
Abstrak
Upaya peningkatan penjualan merupakan cara yang dapat dilakukan guna meningkatkan produksi yang akan diringi oleh peningkatan pendapatan, peningkatan laba atau keuntungan. Terdapat banyak cara yang bisa dilakukan untuk meningkatkan penjualan diantaranya menyebarkan informasi melalui promosi, potongan harga, memperbaiki kualitas produk, melakukan kerjasama dengan pihak lain. Desa Kutosari adalah salah satu desa yang berada di wilayah Kabupaten OKU Timur, Kecamatan Belitang III. Salah satu mata pencaharian penduduk adalah sebagai pembuat batu bata. Selain bahan baku yang mudah didapat, pembuatan batu bata memang sudah menjadi keahlian sebagian besar penduduk, karena produksi batu bata ini telah dilakukan secara turun temurun. Selama ini pemasaran batu bata di Desa Kuto sari dilakukan oleh penjual yang hanya meletakkan produk di depan rumah masing- masing, menunggu konsumen yang datang sendiri ke lokasi produksi batu bata. Karenanya, pemasaran batu bata harus ditingkatkan dengan cara lebih gencar lagi dengan promosi melalui media sosial, online, datang ke toko-toko bangunan untuk melakukan kerjasama dan masih banyak hal lainnya agar peningkatan penjualan produk batu bata dapat tercapai di desa Kuto sari.
\end{abstract}

Kata kunci: peningkatan penjualan, batu bata

\section{PENDAHULUAN}

Desa Kuto sari adalah suatu desa yang letaknya dalam wilayah Kecamatan Belitang III di Kabupaten OKU Timur. Sama hal nya pada desa yang lain di wilayah Republik Indonesia, Desa Kuto sari mempunyai penduduk yang bermata pencaharian beragam mulai dari petani sawah, perkebunan, peternakan dan produsen batu bata. Karenanya sebagian besar lahan digunakan untuk pertanian, dan tanahnya digunakan untuk membuat batu bata.

Ketika kita masuk dalam wilayah desa Kuto sari maka kita akan dapat langsung melihat sajian produk batu bata yang terletak di depan rumah, wilayah pekarangan sebagian besar penduduk desa. Telah dari dahulu Desa ini sangat terkenal dengan produk batu batanya, namun masih banyak calon konsumen yang belum tahu dengan kondisi desa ini, bahwa penduduk desa menjual batu bata jika konsumen tidak datang sendiri ke desa tersebut. Padahal produk batu bata yang dihasikan, kualitasnya sudah sangat baik, meskipun tehnik pembuatannya belum dilakukan secara modern. Bahan baku yang digunakan menggunakan tanah liat yang berkualitas, karena kondisi desa Kuto sari memiliki tekstur tanah yang baik. 
Defenisi Peningkatan menurut Sugono merupakan proses perbuatan, cara meningkatkan. Sedang menurut Alwi peningkatan merupakan suatu proses perbuatan, cara peningkatan usaha dan sebagainya. Sedangkan menurut KBBI, peningkatan merupakan tahapan, cara meningkatkan (usaha, kegiatan). Dari pendapat diatas dapat diambil kesimpulan peningkatan merupakan suatu proses ataupun suatu cara yang dapat dilakukan untuk menjadi lebih baik lagi. Sesuai dengan PKM ini, maka yang dimaksud peningkatan adalah suatu proses ataupun cara yang dilakukan supaya penjualan batu bata di desa Kuto sari dapat lebih semakin meningkat sehingga keuntungan penduduk dapat meningkat pula.

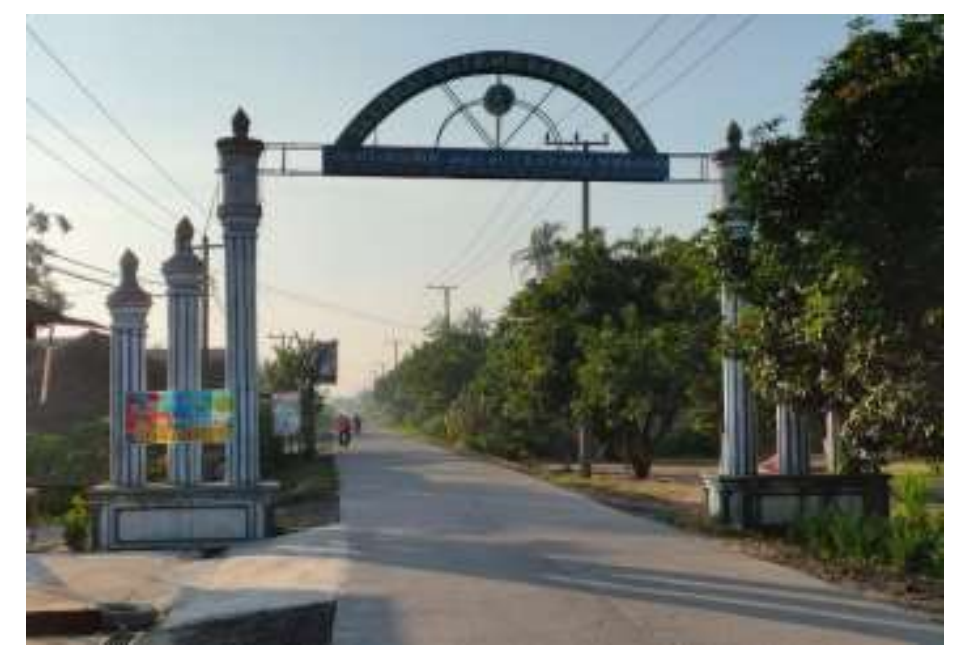

Gambar 1. Gerbang desa Kuto sari Kecamatan Belitang III OKU Timur

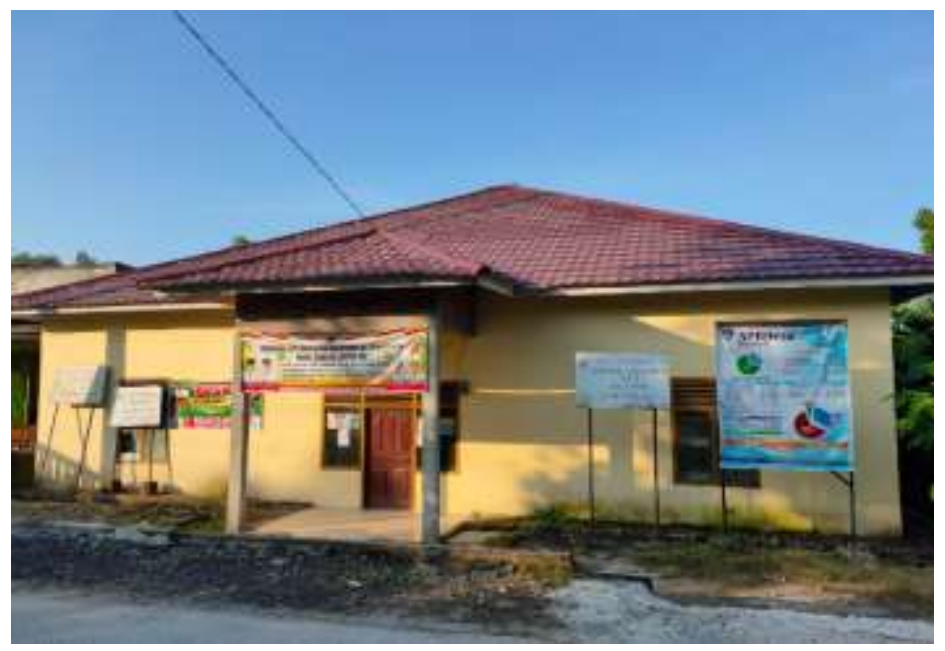

Gambar 2. Kantor Desa Kuto Sari Kecamatan Belitang III OKU Timur

Penjualan ialah suatu kegiatan usaha yang terpadu dengan tujuan pengembangan dari perencanaan strategis yang terarah kepada upaya pemenuhan keinginan serta kebutuhan pembeli, demi memperoleh penjualan yang menimbulkan keuntungan (Marwan, 1991). Penjualan ialah dasar kehidupan sebuah perusahaan, hal ini dikarenakan penjualan bisa menghasilkan laba, selain itu hal tersebut juga dapat menarik pelanggan yang diupayakan guna memahami ketertarikan pelanggan sehingga bisa mengerti bagaimana produk yang telah dikeluarkan. Pendapat Moekijat (Buku Kamus Istilah Ekonomi) mengatakan "selling" melakukan penjualan ialah aktivitas yang diperuntukkan dalam mengejar pembeli, memberikan pengaruh serta memberi pedoman supaya konsumen bisa mendapatkan kesesuaian antara apa yang dibutuhkannya dengan penawaran produknya juga melaksanakan perjanjian tentang harga yang tepat bagi keduanya (2000:488). Pendapat Philip Kotler, terjemahan dari Ronny A. Rusli dan 
Hendra pada buku "Manajemen Pemasaran" pengertian penjualan adalah tahapan kordial administrartif baik perorangan maupun berkelompok memperoleh segala kebutuhan dan keinginannya, membuat, menjajakan serta menukarkan kepada pihak lain berupa barang atau jasa yang mempunyai nilai. (2000:48). Pendapat Nitisemito (1998:13) menyatakan bahwa "penjualan ialah semua kegiatan yang bertujuan untuk melancarkan arus barang dan jasa dari produsen ke konsumen secara paling efisien dengan maksud untuk menciptakan permintaan yang efektif". Secara umum peningkatan penjualan dalam PKM ini adalah rangkaian kegiatan dalam meningkatkan penjualan batu bata.

Batu bata adalah bahan material yang digunakan pada proses pembuatan dinding. Batu bata tercipta dari pembakaran tanah liat sampai warnanya berubah memerah. Batu Bata Tanah Liat, terbentuk dari tanah liat dengan 2 jenis yaitu 1) bata biasa dan 2) bata muka. Bata biasa mempunyai permukaan serta warna yang tak menentu, bata ini dapat dipakai untuk dinding yang memakai morta/campuran semen sebagai pengikat. Jenis bata ini seringkali disebut juga sebagai bata merah. Bata merah merupakan suatu jenis bahan utama dalam proses membangun rumah yang sudah sangat umum dipakai sejak dahulu sampai kini. Sekarang bata merah memanglah merupakan bahan yang harus dipakai pada pembangunan rumah. Dapat dimaklumi, bata merah lebih sering dipakai jika dibandingkan dengan pemakaian bata ringan ataupun batako press, hal ini dikarenakan selain telah teruji kekokohannya serta mudah diperoleh.

Yang dimaksud bata merah ini adalah bata yang terbuat dari tanah yang telah dibentuk lalu melalui proses pembakaran dengan suhu yang tinggi sehingga sepenuhnya mengering, menjadi keras, serta warnanya memerah. Tanahnya pun tidaklah asal-asalan tanah, melainkan tanah yang teksturnya agak liat agar dapat menjadi satu dalam tahap mencetak. Hal inilah yang membuat dinding suatu rumah yang terbuat dari bahan bata merah menjadi dapat terasa adem dan lebih nyaman. Selain tahan lama, lebih kuat, serta kokoh, sehingga dinding yang terbangun dari material bata merah jarang sekali terjadi keretakan. Tak semua tanah liat dapat dipakai. Hanya yang tahan terhadap panas sehingga dapat melindungi bangunan dari bahaya api.

Dilihat dari strukturnya yang memiliki kekuatan yang lebih tahan lama dibandingkan dengan batako, selain itu bata merah juga mudah dalam pemasangannya disebabkan tukang tak butuh keahlian sendiri. Lebih mudah dalam pengangkutan dikarenakan kecilnya ukuran, pada lokasi yang tak luas pun sangat tepat bila memakai material ini. Mudah diperoleh di mana saja. Suhu ruangan lebih nyaman karena dapat beradaptasi dengan suhu luar. Sangat jarang timbul retak-retak pada dinding. Tidak memerlukan perekat khusus. Tahan pula terhadap api.

Bata muka, mempunyai permukaan yang baik serta licin dan juga memiliki corak dan warna yang mirip. Disamping dipakai sebagai dinding juga dapat dipakai menjadi penutup dinding dan digunakan sebagai dekorasi.

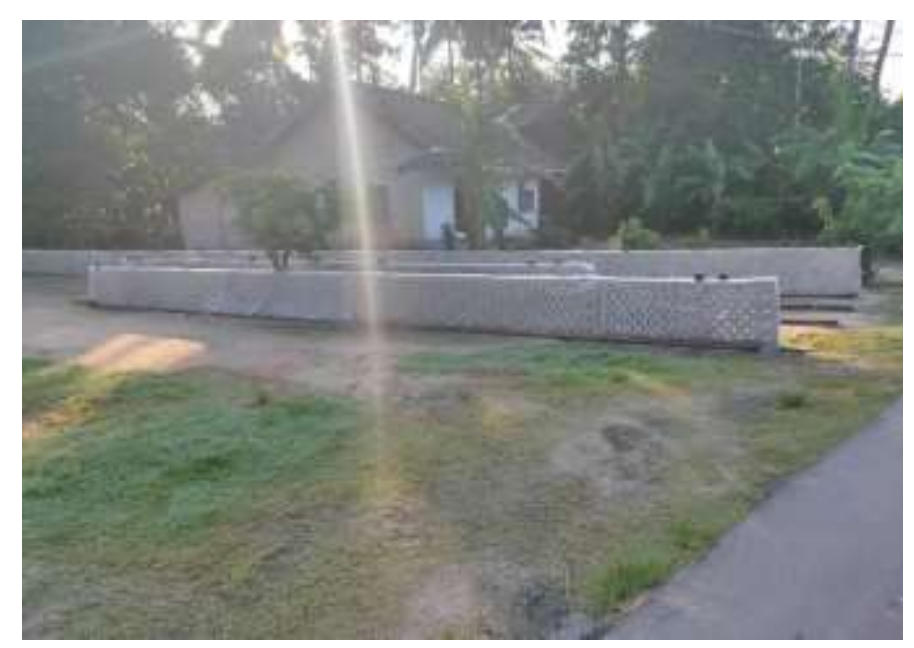

Gambar 3. Produk Batu bata Desa Kuto Sari Kecamatan Belitang III OKU Timur 
Batu Bata Pasir - Kapur, seperti sebutan namanya batu bata ini terbuat dari gabungan bahan kapur serta pasir, perbandingannya yaitu 1: 8 juga air yang ditekankan ke dalam campuran sehingga batu bata dapat terbentuk.

Sasaran penyuluhan adalah penduduk yang membuat atau memproduksi batu bata di Desa Kuto sari. kegiatan yang dilakukan adalah memberikan Penyuluhan yang dilaksanakan melalui penyampaian materi oleh penyuluh kepada para penduduk mengenai bagaimana cara meningkatkan penjualan produk batu bata.

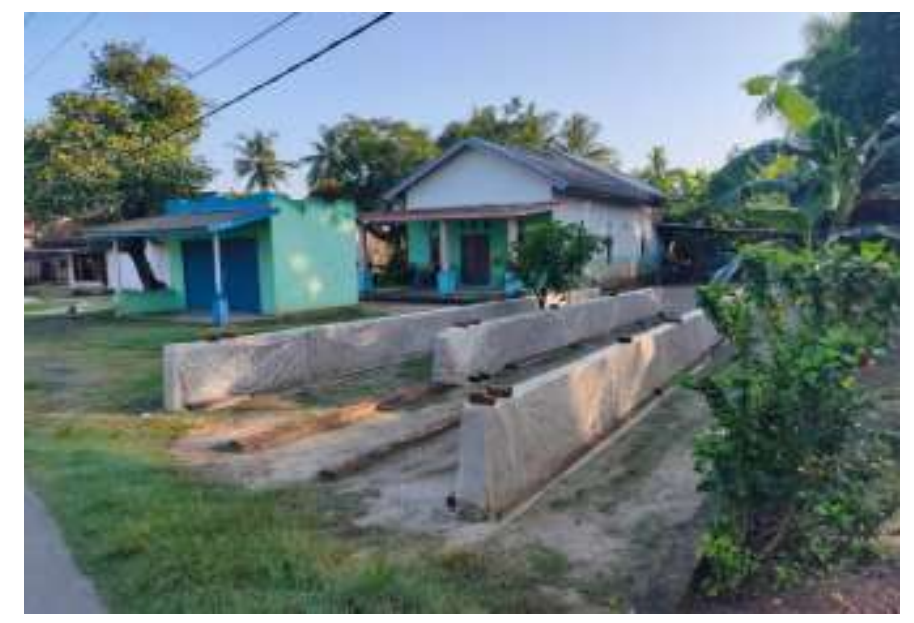

Gambar 4. Produk Batu bata Desa Kuto Sari Kecamatan Belitang III OKU Timur

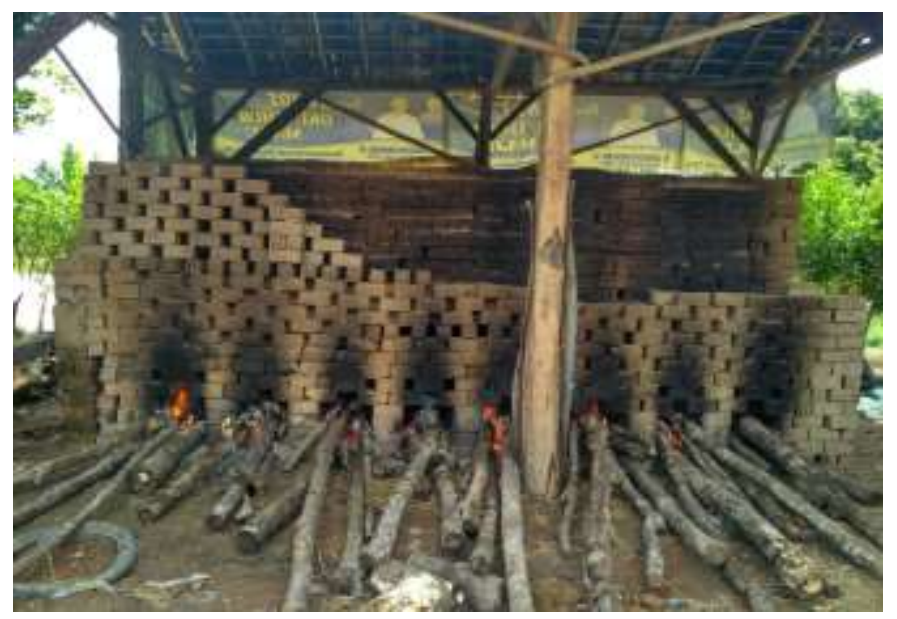

Gambar 5. Proses Batu Bata dibakar

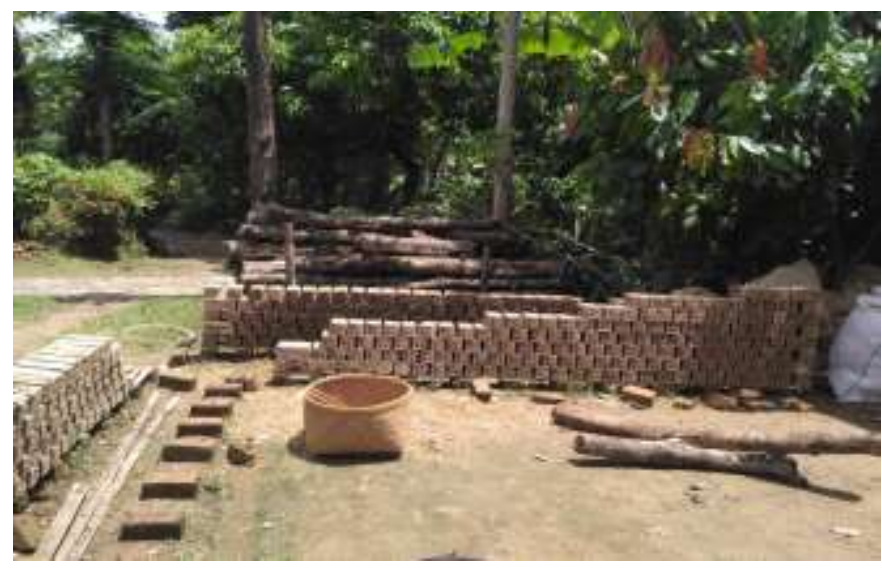

Gambar 6. Produk Batu Bata 


\section{METODE}

Metode yang digunakan untuk mencapai tujuan yang telah dicanangkan dalam kegiatan pengabdian ini adalah sebagai berikut:

a. Kegiatan PKM di desa Kuto sari dilaksanakan sesuai dengan waktu dan tempat yang ditentukan oleh Penyuluh dan Para penduduk secara berkala.

b. Sasaran penyuluhan adalah penduduk yang merupakan pembuat batu bata yang ada dalam wilayah desa Kuto Sari.

c. Metode Penyuluhan ini dilaksanakan melalui penyampaian materi oleh penyuluh kepada para petani mengenai bagaimana penjualan batu bata agar dapat meningkat.

Materi yang diberikan yaitu berupa ceramah dan diskusi-diskusi untuk mendapatkan solusi yang terbaik. Jadi langsung diberikan atau disampaikan kepada penduduk bertempat di Desa Kuto Sari.

\section{HASIL DAN PEMBAHASAN}

Upaya peningkatan penjualan produk batu bata dapat dilakukan dengan berbagai cara. Selama ini penduduk memasarkan produk hanya menggunakan cara tradisional, maka saat ini diberikan pengetahuan bagaimana cara efektif agar produk batu bata dapat meningkat penjualannya. Pada dasarnya terdapat beberapa faktor yang mempengaruhi kegiatan penjualan yaitu kemampuan serta keadaan penjual. Diperlukan kemampuan penjual untuk meyakinkan para pembelinya agar target penjualan yang diinginkan dapat tercapai. Oleh karena itu, penjual pun harus dapat menelaah apa saja persoalan utama yang dapat mempengaruhi, yaitu ciri khas dan karakteristik produk yang nantinya dijual, jenis batu bata, spesifikasi, harga batu bata (memberikan potongan harga atau tempo pembayaran untuk pelanggan tetap), memberikan hal yang berhubungan dengan syarat-syarat penjualan seperti pengantaran, pelayanan setelah penjualan, garansi dan lain-lain. Dalam menganalisis keadaan pasar, haruslah memperhatikan sasaran penjualan dan hal berkaitan dengan pembeli.

Dengan memperhatikan beberapa hal tersebut di atas, bagian terpenting tentunyaa dalam hal pemasaran. Dengan promosi yang baik akan mendapatkan nilai tambah yang lebih tinggi, hal ini harus dibarengi dengan pemasaran yang baik. Pemasaran hasil produksi berupa batu bata yaitu kegiatan usaha penjualan produk yang berupa batu bata sesuai dengan yang dibutuhkan dan diinginkan konsumen, dengan tujuan kepuasan konsumen terhadap produk yang dijual.

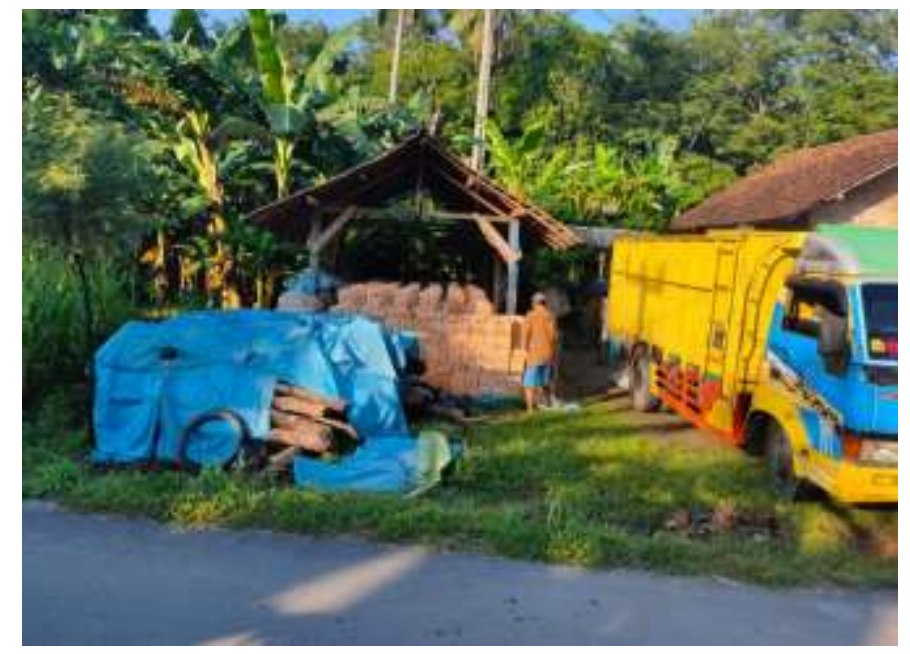

Gambar 7. Proses muat batu bata untuk dikirim ke pembeli

Pemasaran menjadi kunci utama dalam usaha peningkatan penjualan. Tantangan yang paling besar adalah banyaknya perbedaan harga antara produk yang satu dengan lainnya. Itulah 
sebabnya maka produsen harus jeli dalam masalah ini. Memberikan harga yang lebih murah, memberikan potongan harga, atau memberikan keuntungan tambahan lainnya dapat dilakukan agar calon pembeli tertarik untuk membeli produk batu bata desa Kuto sari. Hal lain bisa adalah melakukan kerja sama dengan toko-toko bangunan di berbagai daerah terutama wilayah ogan komering ulu timur.

Hal lain dapat dilakukan dengan gencar promosi di media sosial, iklan di berbagai group penjualan online dengan menampilkan foto-foto batu bata yang menarik. Saat ini medsos menguasai hampir seluruh kehidupan disetiap lapisan masyarakat. Di Era Milenial ini sistem belanja yang paling digemari adalah belanja melalui Online oleh sebab itulah pemasaran batu bata dengan sistem online sangat tepat. Apalagi di Desa Kuto sari internet sudah berjalan dengan baik. Diharapkan pemasaran lewat online dapat meningkatkan penjualan batu bata. karena dengan melalui media online akan lebih meluas cakupan wilayah pemasaran.

Pembentukan Koperasi Agar pemasaran hasil batu bata dapat meningkat perlu mendirikan Koperasi yang anggotanya khusus para penjual batu bata. Karena koperasi merupakan organisasi bersifat bisnis untuk mencapai kepentingan bersama, melalui koperasi juga pemasaran batu bata dapat dilakukan, sehingga akan menambah meningkatnya permintaan masyarakat terhadap batu bata. Perlu Dukungan Perbankan agar pemasaran batu bata dapat berjalan lancar perlu khususnya Perbankan daerah yang merupakan lembaga pembiayaan Perbankan daerah sangatlah penting dalam penentuan keberhasilan produk daerah. Kegiatan perbankan yaitu mengumpulkan dana dari masyarakat dan membagikan lagi kepada masyarakat. Perbankan Daerah tentu amat berguna untuk para pembuat batu bata dalam menjalankan usaha khususnya menambah modal produksi dan tentunya akanmeningkatkan pemasaran.

\section{KESIMPULAN}

Simpulan Dari hasil kegiatan PKM di Desa Kuto sari dapat disimpulkan bahwa batu bata adalah produk yang dihasilkan melalui proses pembuatan tanpa menggunakan alat atau mesin modern. Proses pembuatan sangat ramah lingkungan karena menggunakan cara tradisional. Agar pemasaran batu bata ini terus meningkat maka perlu langkah-langkah yang dilakukan oleh para penjual yaitu selain terus meningkatkan kwalitas dan kwantitas produksi, maka penjual juga harus tetap menjalin hubungan baik dengan konsumen, memberikan harga yang baik, potongan harga, bonus tambahan lain, promosi melalui media sosial / media online, kerjasama dengan toko toko bangunan, pembentukan Koperasi dan juga perlu dukungan Perbankan.

Agar produksi batu bata dapat menghasilkan lebih banyak lagi, maka perlu tambahan kegiatan promosi, meningkatkan kualitas produk, harga yang bersaing, dan sering membuat promosi di media social / media online dengan menggunakan foto terbaik dan menarik, sehingga Desa Kuto sari terkenal dengan produksi batu bata dan terkenal keseluruh pelosok nusantara. Pemasaran batu bata melalui Online harus segera dilaksanakan, karena cara pemasaran lewat online selain dapat mempromosikan batu bata lewat gambar yang menarik dan menjadikan pula konsumen tertarik untuk membelinya.

\section{DAFTAR PUSTAKA}

Alwi, Hasan. Dkk (2002). Kamus Besar Bahasa Indonesia. Jakarta: Balai Pustaka.

Kotler, Philip and Gary Amstrong 2008. Prinsip-Prinsip Pemasaran Edisi 12 Jilid I. Jakarta: Erlangga

Philip \& Ducan 2005. Manajemen Pemasaran Jilid 2. Jakarta: PT. Indeks Kelompok Gramedia Sugono, D. Dkk (2008). Kamus Besar Bahasa Indonesia Edisi Keempat. Jakarta: PT. Gramedia Pustaka Utama

Swastha dan Irawan 2004. Manajemen Pemasaran Modern. Surabaya Liberty 
Yuliana Yeti, Sartika Dewi, Nudin Udayana Samsu, Herdiana Novita, Anung Putri Sari P, (2020), Introduksi Produk Olahan Ubi Jalar pada Anggota Ika Tanjung Sakti, Bandar Lampung, Dinamisia: Jurnal Pengabdian Kepada Masyarakat, Volume 4, No. 2.

KBBI Daring Edisi III. Hak Cipta Badan Pengembangan dan Pembinaan Bahasa (Pusat Bahasa) Kemdikbud

http://www.jurnal.stie-aas.ac.id/index.php/JAIM/article/view/1023/524

https://www.arsitag.com/article/kenali-jenis-dan-fungsi-batu-bata

https://id.wikipedia.org/wiki/Batu_bata

https://www.gurupendidikan.co.id/pengertian-penjualan/\#ftoc-heading-11

https://journal.unilak.ac.id/index.php/dinamisia/article/view/2848 